九州大学学術情報リポジトリ

Kyushu University Institutional Repository

\title{
Chemical Properties of Paddy Soils in Thailand and Malaysia
}

\section{Kai, Hideaki}

Laboratory of Plant Nutrition and Soil Biochemistry, Faculty of Agriculture, Kyushu University

Masayna, Wittaya

Laboratory of Plant Nutrition and Soil Biochemistry, Faculty of Agriculture, Kyushu University

Aibe, Toshiharu

Laboratory of Plant Nutrition and Soil Biochemistry, Faculty of Agriculture, Kyushu University

Hamada, Eisuke

Laboratory of Plant Nutrition and Soil Biochemistry, Faculty of Agriculture, Kyushu University 他

https://doi.org/10.5109/23732

出版情報：九州大学大学院農学研究院紀要. 25 (4)，pp.241-249，1981-04. Kyushu University バージョン：

権利関係 : 


\title{
Chemical Properties of Paddy Soils in Thailand and M alaysia
}

\author{
Hideaki Kai, Wittaya Masayna, Toshiharu Aibe, \\ Eisuke Hamada, Suchart Jiraporncharoen \\ and Yoshio Yamada \\ Laboratory of Plant Nutrition and Soil Biochemistry, Faculty \\ of Agriculture, Kyushu University 46-02, Fukuoka 812
}

\section{Sorasith Vacharotayan}

Faculty of Agriculture, Kasetsart University, Bangkhen, Bangkok, Thailand

Wisit Cholitkul and Chob Kanareugsa

Ministry of Agriculture and Cooperatives, Bangkhen,

Bangkok, Thailand

(Received January 29, 1981)

\begin{abstract}
As a part of International Cooperative Studies on the Increasing Productivity of Soils in Tropical Area (1976-1978). chemical properties of paddy soils in Thailand and Malaysia were studied for the purpose of elucidation of the fundamental characteristics of the soils so as to evaluate soil fertility and to implement advanced technical practices for higher production of rice. Each several soil samples were collected from the central, northern, northeastern and southern regions of Thailand and the western Malaysia. Research in soil chemical analysis has led to findings which are of great significance to soil fertility. On the basis of analytical data fertility of the soils were evaluated, and soil series were classified into the three categories of low, moderate and high fertility according to the inherent fertility of their surface soils. Soils from the soil series of low and moderate fertility have many defective characters which should be ameliorated, such as low $\mathrm{pH}$, low contents of available nitrogen, phosphorus and/or potassium and high salinity. However, it might be not so troublesome problems to ameliorate these soils, when the problems of water are resolved.
\end{abstract}

\section{INTRODUCTION}

Rice production in Thailand exceeds the domestic demand. However, there is a possibility of a deficit of food due to the increase of population at a high rate of 3.0 percent per year. Rice production for the last decade increased 20 percent, but the increase of yield per unit area is only 2.4 percent which is the least in tropical Asian countries. The increased production of outputs for the last decade was largely due to the expansion of cultivated land, but it should be increased in terms of yield per unit area in the future. For instance, the 1.8 ton rice yield per hectare is still relatively low as com- 
pared to that of developed countries. This is due to less diffusion of modern agricultural techniques using fertilizers, and due to the extension of the relatively unproductive lands. It is necessary to increase the soil fertility and to improve the less productive soils distributed in Thailand.

West Malaysia still imports rice to feed her population. Rice production for the last decade in this country increased 50 percent, but the increase was also mainly due to the expansion of cultivated land. Here, the increase of yield per unit area is also necessary.

To get the basic data to improve the soil fertility in both countries, we initiated a project to conduct field survey and laboratory work in 1977 and 1978. Clay mineralogy study is presented by Wada et al. (1981). Here we would like to present a chemical properties study.

\section{MATERIALS AND METHODS}

Soil samples

Field studies and soil sampling were carried out in December 1977 and 1978. These details are described by Wada et al. (1981) in a separate paper and description of soil samples are also listed in their paper.

Chemical analyses

Chemical analyses were carried out by the following methods (Black et al., 1965) :

1. $\mathrm{pH}$

$\mathrm{pH}$ was measured in $1: 2.5$ soil-water suspension and $1: 2.5$ soil-N KC1 suspension with a glass electrode $\mathrm{pH}$-meter.

\section{Organic carbon}

Organic carbon was determined by a dry-combustion method using CN Corder (Model MT-500 W, Yanagimoto Mfg. Co., Ltd., Japan).

3. Total nitrogen

Total nitrogen was also analyzed by a dry-combustion method using the CN Corder.

\section{Available nitrogen}

Mineralized nitrogen was determined after incubation of air-dried soil samples under submerged condition for 4 weeks at $30^{\circ} \mathrm{C}$.

5. Available phosphorus

Available phosphorus was determined by Bray-II method.

6. Cation exchange capacity method.

Cation exchange capacity was measured by the improved Schollenberger

7. Exchangeable bases

Exchangeable bases were determined in leached solution obtained from the procedure of measuring CEC by atomic absorption spectrometry. 


\section{RESULTS AND DISCUSSION}

The results of chemical properties of surface soils are given in Table 1. Although the number of samples is not so diverse, classification of soil series on the basis of the some chemical properties was tentatively carried out to know the tendency of the properties. Debate was done referring to the works of Kawaguchi and Kyuma (1969 a, b, 1977) and Motomura et al. (1979).

\section{pH}

Table 2 shows the classification of soil series on the basis of $\mathrm{pH}$ of the surface soils listed in Table 1. Soils from Ongkharak and Thanyaburi series in Bangkok Plain and from Kundor and Guar series in Peninsula region show the $\mathrm{pH}$ less than 4.5. These soils are derived from marine and brackish water deposits and are acid sulfate soils. The acidity of the above soils is followed by the soils from Ayutthaya and Bangkhen series in Bangkok Plain. Soils from Sansai series in Northern Valleys and Roi Et series in Khon Kaen region show more or less low $\mathrm{pH}$ due to their coarse texture and severe weathering and leaching.

All Malaysian soils show the low pH. The following reasons have been suggested (Kawaguchi and Kyuma, 1969 b) : (1) acidic parent rocks, (2) severe leaching by heavy rain, and (3) peaty and/or swampy with sediments of brackish environment. Soils from Lop Buri series which is derived from weathered calcareous materials, shows nearly neutral pH. The $\mathrm{pH}$ of the paddy soil usually increases in submerged conditions and rice plant is tolerant to a relatively low $\mathrm{pH}$. Thus, as far as our investigations of $\mathrm{pH}$ values of paddy soils under cultivation in general of Thailand and Malaysia are concerned, a low $\mathrm{pH}$ value does not seem to be a severe problem.

\section{Organic carbon}

It is well known that organic matter becomes decomposable after being exposed to dry conditions. As the dry season in Thailand is quite remarkable and the temperature is very high after flooding, organic matter is decomposed easily. That is one of the reasons why the carbon content in Thai soils is generally lower than that of Japanese soils. The organic carbon content in soils from Khon Kaen region is the lowest. This seems to be due to their coarse texture. Carbon content in soils of Bangkok Plain is rather high, particularly in acid sulfate soils due to the low decomposition rate of organic matter under such low pH condition. In Northern Valleys, the carbon content in soils of Sansai series is lower than that of Phimai series. It also seems to be due to the difference of their texture. West Malaysian soils show rather higher content of carbon. One reason is the wet climate throughout the year and the other is the low decomposition rate of organic matter in acid soil.

Total nitrogen and $\mathrm{C} / \mathrm{N}$ ratio

Total nitrogen content in soils in each region shows the same tendency as organic carbon. Accordingly, $\mathrm{C} / \mathrm{N}$ ratio changes in a narrow range. The 
Table 1. Chemical properties

\begin{tabular}{|c|c|c|c|c|c|c|c|}
\hline \multirow{2}{*}{\multicolumn{2}{|c|}{ Region }} & \multirow{2}{*}{ Soil series } & \multirow{2}{*}{$\begin{array}{l}\text { Site } \\
\text { No. }\end{array}$} & \multirow{2}{*}{ Texture } & \multicolumn{2}{|c|}{$\mathrm{pH}$} & \multirow{2}{*}{$\begin{array}{c}\text { Org. } \\
(\%)\end{array}$} \\
\hline & & & & & $\left(\mathrm{H}_{2} \mathrm{O}\right)$ & $(\mathrm{KCl})$ & \\
\hline & $\begin{array}{l}\text { Northern } \\
\text { Valleys }\end{array}$ & $\begin{array}{l}\text { Sansai } \\
\text { Hangdong-Phimai } \\
\text { Phimai }\end{array}$ & $\begin{array}{l}\text { T L }-1 \\
\text { T L }-2 \\
\text { T L }-4 \\
\text { T L }-3 \\
\text { T L }-5 \\
\text { T L }-6\end{array}$ & $\begin{array}{l}\text { SL } \\
\text { SL } \\
\text { L } \\
\text { S C L } \\
\mathrm{LiC} \\
\mathrm{HC}\end{array}$ & $\begin{array}{l}\text { 4. } 50 \\
\text { 5. } 35 \\
\text { 5. } 20 \\
\text { 5. } 22 \\
\text { 5. } 88 \\
\text { 5. } 35\end{array}$ & $\begin{array}{l}3.95 \\
4.30 \\
4.43 \\
\text { 3. } 77 \\
4.82 \\
4.13\end{array}$ & $\begin{array}{l}0.60 \\
0.73 \\
0.46 \\
0.94 \\
1.61 \\
1.47\end{array}$ \\
\hline II. & Khon Kaen & $\begin{array}{l}\text { Roi Et } \\
\text { Ratchaburi }\end{array}$ & $\begin{array}{l}\text { T L }-8 \\
\text { T L }-9 \\
\text { T L }-7\end{array}$ & $\begin{array}{l}\text { S L } \\
\text { L S } \\
\text { LiC }\end{array}$ & $\begin{array}{l}5.53 \\
4.80 \\
5.50\end{array}$ & $\begin{array}{l}3.82 \\
3.90 \\
4.00\end{array}$ & $\begin{array}{l}0.44 \\
0.28 \\
0.78\end{array}$ \\
\hline III. & $\begin{array}{l}\text { Bangkok } \\
\text { Plain }\end{array}$ & $\begin{array}{l}\text { Klaeng } \\
\text { Saraburi } \\
\text { Ongkharak } \\
\text { Thanyaburi } \\
\text { Ayutthaya } \\
\text { Bangkhen } \\
\text { Bangkok } \\
\text { Lop Buri11 }\end{array}$ & $\begin{array}{cc}\mathrm{T} & \mathrm{L}-25 \\
\mathrm{~T} & \mathrm{~L}-12 \\
\mathrm{~T} & \mathrm{~L}-29 \\
\mathrm{~T} & \mathrm{~L}-10 \\
\mathrm{~T} & \mathrm{~L}-13 \\
\mathrm{~T} & \mathrm{~L}-21 \\
\mathrm{~T} & \mathrm{~L}-22 \\
\mathrm{~T} & \mathrm{~L}-23 \\
\mathrm{~T} & \mathrm{~L}-24 \\
\mathrm{~T} & \mathrm{~L}-27\end{array}$ & $\begin{array}{l}\mathrm{S} \mathrm{L} \\
\mathrm{LiC} \\
\mathrm{HCC} \\
\mathrm{HCC} \\
\mathrm{SiC} \\
\mathrm{HC} \\
\mathrm{HC} \\
\mathrm{HC} \\
\mathrm{HC} \\
\mathrm{HC}\end{array}$ & $\begin{array}{l}4.56 \\
5.77 \\
4.27 \\
4.00 \\
4.84 \\
5.02 \\
5.12 \\
5.08 \\
5.70 \\
6.84\end{array}$ & $\begin{array}{l}3.93 \\
4.60 \\
3.61 \\
3.28 \\
4.05 \\
4.21 \\
4.48 \\
4.19 \\
4.98 \\
5.65\end{array}$ & $\begin{array}{l}0.78 \\
0.97 \\
3.01 \\
1.68 \\
1.06 \\
1.68 \\
2.39 \\
1.45 \\
2.37 \\
1.49\end{array}$ \\
\hline $\begin{array}{l}\text { IV. } \\
\text { a. }\end{array}$ & $\begin{array}{l}\text { Peninsula } \\
\text { Southeast } \\
\text { Coast } \\
\text { (Thailand) }\end{array}$ & $\begin{array}{l}\text { Klaeng } \\
\text { Samut Prakan }\end{array}$ & $\begin{array}{l}\text { TL }-31 \\
\text { T L }-32 \\
\text { T L-30 }\end{array}$ & $\begin{array}{l}\mathrm{LiC} \\
\mathrm{CL} \\
\mathrm{H} \mathrm{C}\end{array}$ & $\begin{array}{l}4.89 \\
4.32 \\
5.80\end{array}$ & $\begin{array}{l}4.12 \\
3.88 \\
4.80\end{array}$ & $\begin{array}{l}0.89 \\
0.72 \\
2.27\end{array}$ \\
\hline b. & $\begin{array}{l}\text { Middle } \\
\text { West } \\
\text { (Malaysia) }\end{array}$ & $\begin{array}{l}\text { Hutan } \\
\text { Tualang-Kundor } \\
\text { Kundor } \\
\text { Guar }\end{array}$ & $\begin{array}{l}\text { ML-13 } \\
\text { ML-11 } \\
\text { ML-14 } \\
\text { ML-15 }\end{array}$ & $\begin{array}{l}\mathrm{H} \mathrm{C} \\
\mathrm{H} \mathrm{C} \\
\mathrm{HC} \\
\mathrm{LiC}\end{array}$ & $\begin{array}{l}4.42 \\
4.45 \\
4.28 \\
3.89\end{array}$ & $\begin{array}{l}3.51 \\
3.75 \\
3.59 \\
3.44\end{array}$ & $\begin{array}{l}2.71 \\
2.07 \\
3.28 \\
4.06\end{array}$ \\
\hline
\end{tabular}

1) Soil sample description of TL-27 is not shown in separate paper written by Wada Lop Buri series ; and Farmer's field.

Table 2. Soil series classified according to the $\mathrm{pH}$ value of surface soils.

\begin{tabular}{r|c}
\hline $\mathrm{pH}\left(\mathrm{H}_{2} \mathrm{O}\right)$ & Soil series (Region) \\
\hline$<4.5$ & Ongkharak, Thanyaburi (III), Hutan, Tualang-Kundor, Kundor, Guar (IV) \\
$4.5-5.5$ & $\begin{array}{c}\text { Sansai, Hangdong-Phimai (I), Roi Et (II), Klaeng, Ayutthaya, Bangkhen. } \\
\text { Bangkok (III), Klaeng (IV) }\end{array}$ \\
$>5.5$ & Phimai (I), Ratchaburi (II), Saraburi, Lop Buri (III), Samut Prakan (IV) \\
\hline
\end{tabular}

nitrogen content in soils of Bangkok Plain and West Malaysia is rather higher than that of other regions. This tendency is attributable to the same reasons previously explained for the case of organic carbon in both regions.

\section{Available nitrogen}

Available nitrogen is particularly important in Southeast Asia, where the amount of fertilizer applied is rather low. However, the amount of $\mathrm{NH}_{4}-\mathrm{N}$ mineralized during 4 weeks in the soils of this area is remarkably lower than that of Japan. This is due to the low content of organic matter in these soils. 
of surface soils.

\begin{tabular}{|c|c|c|c|c|c|c|c|c|c|}
\hline $\begin{array}{l}\text { Total } \\
\mathrm{N} \\
(\%) \\
\end{array}$ & $\mathrm{C} / \mathrm{N}$ & \multicolumn{2}{|c|}{$\begin{array}{c}\mathrm{NH},-\mathrm{N} \\
\text { mineralized } \\
(\mathrm{mg} / 100 \mathrm{~g})(\%)\end{array}$} & $\begin{array}{c}\text { Avail. } \\
\mathrm{P}_{2} \mathrm{O}_{5} \\
(\mathrm{mg} / 100 \mathrm{~g}) \\
\end{array}$ & $\begin{array}{r}\mathrm{CEC} \\
\mathrm{me} / 100 \mathrm{~g}) \\
\end{array}$ & $\overline{\mathrm{Na}}$ & $\begin{array}{l}\text { Excha } \\
\mathrm{K} \\
(\mathrm{me} / 10 \\
\end{array}$ & $\begin{array}{l}\text { geable } \\
\qquad \mathrm{Ca} \\
\mathrm{g} \text { soil) }\end{array}$ & $\mathrm{Mg}$ \\
\hline $\begin{array}{l}0.038 \\
0.056 \\
0.041 \\
0.082 \\
0.143 \\
0.150\end{array}$ & $\begin{array}{r}15.8 \\
13.0 \\
11.2 \\
11.5 \\
11.3 \\
9.8\end{array}$ & $\begin{array}{l}1.66 \\
4.88 \\
1.93 \\
5.18 \\
9.29 \\
5.29\end{array}$ & $\begin{array}{l}4.37 \\
8.71 \\
4.71 \\
6.32 \\
6.50 \\
3.53\end{array}$ & $\begin{array}{r}28.80 \\
0.64 \\
0.34 \\
2.24 \\
0.21 \\
1.28\end{array}$ & $\begin{array}{r}2.03 \\
3.98 \\
1.78 \\
12.95 \\
10.27 \\
18.62\end{array}$ & $\begin{array}{l}0.04 \\
0.12 \\
0.08 \\
0.08 \\
0.21 \\
0.13\end{array}$ & $\begin{array}{l}0.03 \\
0.05 \\
0.04 \\
0.13 \\
0.28 \\
0.51\end{array}$ & $\begin{array}{r}\mathbf{0 . 9 6} \\
2.56 \\
1.88 \\
6.07 \\
10.66 \\
10.60\end{array}$ & $\begin{array}{l}0.10 \\
0.61 \\
0.32 \\
1.24 \\
2.22 \\
1.61\end{array}$ \\
\hline $\begin{array}{l}0.043 \\
0.025 \\
0.070\end{array}$ & $\begin{array}{l}10.2 \\
11.2 \\
11.1\end{array}$ & $\begin{array}{l}3.00 \\
2.18 \\
2 . \mathrm{a} 4\end{array}$ & $\begin{array}{l}6.98 \\
8.72 \\
4.06\end{array}$ & $\begin{array}{l}0.96 \\
0.30 \\
1.12\end{array}$ & $\begin{array}{r}5.18 \\
3.05 \\
15.54\end{array}$ & $\begin{array}{l}0.14 \\
1.10 \\
0.26\end{array}$ & $\begin{array}{l}0.04 \\
0.08 \\
0.30\end{array}$ & $\begin{array}{l}1.53 \\
7.84 \\
7.66\end{array}$ & $\begin{array}{l}0.44 \\
1.30 \\
2.48\end{array}$ \\
\hline $\begin{array}{l}0.060 \\
0.092 \\
0.223 \\
0.190 \\
0.012 \\
0.149 \\
0.260 \\
0.139 \\
0.192 \\
0.058\end{array}$ & $\begin{array}{r}13.0 \\
10.5 \\
13.5 \\
8.8 \\
10.4 \\
11.3 \\
9.4 \\
10.5 \\
12.3 \\
25.8\end{array}$ & $\begin{array}{r}3.44 \\
3.68 \\
1.79 \\
3.16 \\
3.21 \\
7.73 \\
11.23 \\
1.57 \\
5.37 \\
4.52\end{array}$ & $\begin{array}{l}5.73 \\
4.00 \\
0.57 \\
1.66 \\
3.15 \\
5.19 \\
4.40 \\
1.13 \\
2.79 \\
7.79\end{array}$ & $\begin{array}{l}2.27 \\
0.88 \\
2.80 \\
0.72 \\
0.48 \\
3.56 \\
3.90 \\
1.67 \\
2.60 \\
1.58\end{array}$ & $\begin{array}{r}9.77 \\
19.62 \\
19.42 \\
25.50 \\
19.02 \\
15.78 \\
20.86 \\
21.52 \\
20.25 \\
32.97\end{array}$ & $\begin{array}{l}1.47 \\
0.34 \\
1.21 \\
1.46 \\
0.94 \\
0.35 \\
1.21 \\
2.15 \\
2.27 \\
0.59\end{array}$ & $\begin{array}{l}0.41 \\
0.23 \\
0.33 \\
0.53 \\
0.53 \\
0.37 \\
0.77 \\
0.90 \\
0 . \mathrm{a} 3 \\
0.27\end{array}$ & $\begin{array}{r}5.68 \\
10.75 \\
1.68 \\
7.45 \\
9.18 \\
11.08 \\
13.73 \\
\text { a. a } 2 \\
5.11 \\
36.66\end{array}$ & $\begin{array}{r}4.69 \\
3.14 \\
3.12 \\
6.90 \\
4.74 \\
4.38 \\
8.90 \\
12.81 \\
9.95 \\
4.56\end{array}$ \\
\hline $\begin{array}{l}0.073 \\
0.064 \\
0.158\end{array}$ & $\begin{array}{l}12.1 \\
11.3 \\
14.4\end{array}$ & $\begin{array}{l}2.52 \\
2.84 \\
6.84\end{array}$ & $\begin{array}{l}3.45 \\
4.43 \\
4.33\end{array}$ & $\begin{array}{l}1.82 \\
1.92 \\
2.60\end{array}$ & $\begin{array}{r}4.16 \\
2.56 \\
20.27\end{array}$ & $\begin{array}{l}0.13 \\
0.15 \\
1.51\end{array}$ & $\begin{array}{l}0.05 \\
0.07 \\
0.42\end{array}$ & $\begin{array}{l}3.12 \\
0.97 \\
9.04\end{array}$ & $\begin{array}{r}0.25 \\
0.39 \\
13.44\end{array}$ \\
\hline $\begin{array}{l}0.250 \\
0.213 \\
0.213 \\
0.313\end{array}$ & $\begin{array}{r}10.8 \\
9.7 \\
15.4 \\
13.0\end{array}$ & $\begin{array}{l}\text { a. } 88 \\
9.22 \\
6.92 \\
1.76\end{array}$ & $\begin{array}{l}3.55 \\
4.33 \\
3.25 \\
0.56\end{array}$ & $\begin{array}{l}\text { 1. a3 } \\
\text { 4.64 } \\
\text { 2. a3 } \\
\text { 5. } 19\end{array}$ & $\begin{array}{l}11.50 \\
10.40 \\
17.22 \\
13.88\end{array}$ & $\begin{array}{l}0.57 \\
0.12 \\
0.55 \\
0.18\end{array}$ & $\begin{array}{l}0.15 \\
0.06 \\
0.21 \\
0.28\end{array}$ & $\begin{array}{l}3.77 \\
2.40 \\
6.86 \\
1.00\end{array}$ & $\begin{array}{l}2.05 \\
5.51 \\
1.53 \\
0.59\end{array}$ \\
\hline
\end{tabular}

et al. (1981). Location soil series; management are Kao-sam-yod. Muang, Lop Buri;

Table 3. Soil series classified according to the available nitrogen mineralized in surface soils under anaerobic condition.

\begin{tabular}{c|l}
$\begin{array}{c}\text { Mineralized } \\
\text { NH }-\mathrm{N} \\
\mathbf{m g} / 100 \mathrm{~g}\end{array}$ & \multicolumn{1}{|c}{ Soil series (Region) } \\
\hline$<5$ & $\begin{array}{l}\text { Sansai (I), Roi Et. Ratchaburi (II), Klaeng. Saraburi, Ongkharak, } \\
\text { Thanyaburi, Bangkok (III), Klaeng, Guar (IV) }\end{array}$ \\
$5-10$ & $\begin{array}{l}\text { Hangdong-Phimai. Phimai (I), Ayutthaya, Lop Buri (III), Samut Prakan, } \\
\text { Hutan. Tualang-Kundor. Kundor (IV) } \\
\text { Bangkhen (III) }\end{array}$ \\
\hline
\end{tabular}

Table 3 shows the classification of soil series on the basis of the content of available nitrogen in surface soils. Phimai series in Northern Valleys, Bangkhen series in Bangkok Plain and Hutan, Tualang-Kundor and Kundor series in Peninsula region show the relatively high available nitrogen.

In a series of experiments conducted by Kai et al. (1979) to study nitrogen behaviour in Thai paddy soils, it was found that the mineralization of native soil nitrogen correlated very well with the absorption of nitrogen by the rice plants. This relation reflects a good index of the nitrogen supplying power 
of Thai paddy soils.

\section{Available phosphorus}

All samples show the low content of available phosphorus except TL-1, which is an exceptional case, and which might have been due to the fact that the soil was heavily dressed with phosphate fertilizer in the previous seasons.

Table 4 shows the classification of soil series on the basis of the content of available phosphorus in surface soils. Less than $2 \mathrm{mg} / 100 \mathrm{~g}$ soil of available $\mathrm{P}_{2} \mathrm{O}_{5}$ are measured in Sansai and Phimai series in Northern Valleys, Roi Et and Ratchaburi series in Khon Kaen region, Saraburi, Thanyaburi and Lop Buri series in Bangkok Plain, and Klaeng and Hutan series in Peninsula region. Application of phosphate fertilizer is essential to increase the rice production in these areas.

Table 4. Soil series classified according to the content of available phosphorus in surface soils.

\begin{tabular}{c|l}
\hline $\begin{array}{c}\text { Available } \\
\mathrm{P}_{2} \mathrm{O}_{5} \\
\mathrm{mg} / 100 \mathrm{~g}\end{array}$ & \multicolumn{1}{|c}{ Soil series (Region) } \\
\hline$<2$ & $\begin{array}{l}\text { Sansai, Phimai (I), Roi Et, Ratchaburi (II), Saraburi. Thanyaburi. } \\
\text { Lop Buri (III), Klaeng. Hutan (IV) }\end{array}$ \\
$2-10$ & $\begin{array}{l}\text { Hangdong-Phimai (I), Klaeng, Ongkharak, Ayutthaya, Bangkhen. } \\
\text { Bangkok (III), Samut Prakan. Tualang-Kundor, Kundor, Guar (IV) } \\
>10\end{array}$ \\
\hline
\end{tabular}

1) Exceptional case.

Table 5. Soil series classified according to the CEC of surface soils.

\begin{tabular}{c|c}
\hline $\begin{array}{c}\text { C E C } \\
\text { me } / 100 \mathrm{~g}\end{array}$ & \multicolumn{1}{c}{ Soil series (Region) } \\
\hline$<6$ & Sansai (I), Roi Et (II), Klaeng (IV) \\
$6-20$ & $\begin{array}{l}\text { Hangdong-Phimai, Phimai (I), Ratchaburi (II), Klaeng, Saraburi, Ongkharak, } \\
\text { Ayutthaya (III), Hutan, Tualang-Kundor, Kundor, Guar (IV) }\end{array}$ \\
$>20$ & Thanyaburi, Bangkhen, Bangkok, Lop Buri (III), Samut Prakan (IV) \\
\hline
\end{tabular}

\section{Cation exchange capacity}

Cation exchange capacity (CEC) is one of the soil characters which well reflect the inherent soil fertility. Table 5 shows the classification of soil series on the basis of the magnitude of CEC of surface soils. Soils of Sansai series in Northern Valleys show the CEC less than $4 \mathrm{me} / 100 \mathrm{~g}$ soil and those of Hangdong-Phimai and Phimai series in the same region show the moderate CEC reflecting the soil texture. Soils of Roi Et series show lower CEC but that of Ratchaburi series shows rather high CEC, in Khon Kaen region.

Acid sulfate soils and those related soils such as Ongkharak, Thanyaburi, Ayutthaya and Bangkhen in Bangkok Plain are fine texture which show rather high CEC. The soil from Lop Buri series is calcareous Grumusol and also 
shows heavy clay texture and very high CEC. In Peninsula region in Thailand, soils of Klaeng series show low CEC but those of Samut Prakan series show higher CEC reflecting the soil texture. Soils in the middle west coast of Malaysia are generally fine texture and show moderate CEC.

\section{Exchangeable $\mathrm{Ca}$ and $\mathrm{Mg}$}

Table 6 shows the classification of soil series on the basis of the content of exchangeable $\mathrm{Ca}$ in surface soils. As TL-9 of Roi Et series is affected by salt bed, exchangeable $\mathrm{Ca}$ and $\mathrm{Mg}$ are extremely high. The soil from Lop Buri series is calcareous Grumusol and exchangeable $\mathrm{Ca}$ is very high in these soils. However, exchangeable $\mathrm{Ca}$ and $\mathrm{Mg}$ in other regions are generally low except for the soils in Bangkok Plain. Soils of Bangkok Plain which are marine clay origin show high exchangeable $\mathbf{M g}$.

Table 6. Soil series classified according to the content of exchangeable $\mathrm{Ca}$ in surface soils.

\begin{tabular}{c|l}
\hline $\begin{array}{c}\text { Exc.-Ca } \\
\text { me } / 100 \mathrm{~g}\end{array}$ & \multicolumn{1}{c}{ Soil series (Region) } \\
\hline$<3.5$ & Sansai (I), Roi Et (II), Ongkharak (III), Klaeng, Tualang-Kundor. \\
$3.5-7$ & Guar (IV) \\
$>7$ & $\begin{array}{l}\text { Pangdong-Phimai (I), Roi Et (I), Klaeng, Bangkok (III), Hutan, Kundor (IV) } \\
\text { Bangkhen, Lop Buri (III), Samut Prakan (IV) }\end{array}$ \\
\hline
\end{tabular}

1) Saline soil.

Table 7. Soil series classified according to the content of exchangeable $\mathrm{K}$ in surface soils.

\begin{tabular}{c|l}
\hline $\begin{array}{c}\text { Exc. }-\mathrm{K} \\
\mathrm{me} / 100 \mathrm{~g}\end{array}$ & \multicolumn{1}{c}{ Soil series (Region) } \\
\hline$<0.15$ & Sansai, Hangdong-Phimai (I), Roi Et (II), Klaeng, Tualang-Kundor (IV) \\
$0.15-0.3$ & Saraburi, Lop Buri (III), Hutan, Kundor, Guar (IV) \\
$>0.3$ & $\begin{array}{l}\text { Phimai (I), Ratchaburi (II), Klaeng, Ongkharak, Thanyaburi. Ayutthaya, } \\
\text { Bangkhen, Bangkok (III), Samut Prakan (IV) }\end{array}$ \\
\hline
\end{tabular}

\section{Exchangeable $\mathrm{Na}$ and $\mathrm{K}$}

Table 7 shows the classification of soil series on the basis of the content of exchangeable $\mathrm{K}$ in the surface soils. Soils from Sansai and Hangdong. Phimai series in Northern Valleys, Roi Et series in Khon Kaen region and Klaeng and Tualang-Kundor series in Peninsula are deficient in potassium. This can be explained by two reasons. One is their relatively coarse texture, low CEC and the other is leaching under the wet condition throughout the year in Peninsula regions.

However, soils from other series show generally higher content of potassium than Japanese soils. Especially soils derived from marine clay have a high sodium and potassium contents. High available $\mathrm{K}$ in Ayuthaya, Bangkhen and Bangkok series and low $\mathrm{K}$ in Klaeng, Tualang-Kundor series may be 
explained by the content of mica in the soils as Wada et al. (1981) has suggested in a separate paper.

\section{Evaluation of the fertility of soils}

Table 8 shows the classification of soil series on the basis of inherent soil fertility which is tentatively proposed from the data mentioned above.

When the problems of water are excluded, soils from Phimai series in Northern Valleys, Bangkhen and Ayutthaya series in Bangkok Plain and Samut Prakan series in Peninsula are very fertile and less problem soils.

Adversely, soils from Sansai series in Northern Valleys, Roi Et series in Khon Kaen region and Tualang-Kundor, Guar and Klaeng series in Peninsula have many defective characters which should be ameliorated. However, as Takahashi et al. (1979) described, it is not a troublesome problem to ameliorate these soils. For instance, yields from Kuan Gut (TL-31) and Pattani (TL-32) in Klaeng series were increased from $2.0 \mathrm{t} / \mathrm{ha}$ to $3.6 \mathrm{t} / \mathrm{ha}$ and from $1.5 \mathrm{t} /$ ha to $4.0 \mathrm{t} /$ ha respectively, by supplying $\mathrm{N}, \mathrm{P}, \mathrm{K}$ fertilizers. Soils from Rangsit (TL-10) and Khlong Luang (TL-13) in Thanyaburi series are amelio-

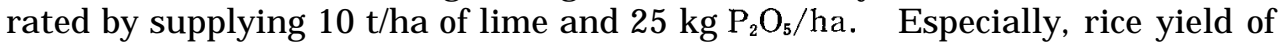
Rangsit Rice Experiment Station (TL-10) where soil is of less problem with the exception of $\mathrm{pH}$ and phosphorus condition, was increased from 2.0 t/ha to $4.9 \mathrm{t} / \mathrm{ha}$ after supplying lime and $\mathrm{N}, \mathrm{P}, \mathrm{K}$ fertilizers.

Table 8. Soil series classified according to the inherent fertility of surface soils.

\begin{tabular}{|c|c|c|}
\hline Fertility & Soil series (Region) & \\
\hline Low & Sansai (I). Roi Et (II), Klaeng, Tualang-Kundor. Guar (IV) & \\
\hline Moderate & $\begin{array}{l}\text { Hangdong-Phimai (I), Ratchaburi (II), Klaeng, Saraburi, } \\
\text { Thanyaburi, Bangkok, Lop Buri (III), Hutan (IV) }\end{array}$ & Ongkharak, \\
\hline High & Phimai (I), Ayutthaya, Bangkhen (III), Samut Prakan (IV) & \\
\hline
\end{tabular}

\section{ACKNOWLEDGEMENTS}

The authors wish to thank the grant given to this International Joint Research Project from the Japan Society for the Promotion of Science and the permission given to us by the National Research Council for the Regulations Governing the Promotion of Foreign Research in Thailand.

The authors also wish to thank Dr. Jisuke Takahashi, Mrs. Jaovapa Hasathon, Miss Jintana Somboondumrongkul in Rice Division and Dr. Manuwetaya Srisen, Mr. Samunao Phetchawee, Mr. Bunharn Tangcham in Division of Agricultural Chemistry, Department of Agriculture (Thailand), Dr. Takanori Igarashi in Tropical Agricultural Research Center (Japan), Dr. Chaitat Pairintra in Faculty of Agriculture, Khon Kaen University, Dr. Niwat Hirunburana in Faculty of Agriculture, Chiang Mai University, Mr. Joseph Samy and Mr. Xavier Arulandoo in Malaysian Agricultural Research and Development Institute, and Dr. Koji Wada, Dr. Motoki Ikeda, Dr. Chitoshi Mizota, Dr. Sadao Kawaguchi 
and Dr. Keizo Tsuchiya in Faculty of Agriculture, Kyushu University for their kind help to study this work.

\section{REFERENCES}

Black, C. A., D. D. Evans, L. E. Ensminger, J. L. White, F. E. Clark and R. C. Dinauer 1965 Methods of Soil Analysis Part 2. Chemical and Microbiological Properties. American Society of Agronomy, Inc., Madison (USA)

Kai. H., M. Wittaya and Y. Yamada 1979 Studies of the nitrogen supplying capacities of some Thai paddy soils. Abst. Meeting Soc. Soil Sci. and Manure, Japan, 25: 100

Kawaguchi. K. and K. Kyuma 1969 a Lowland Rice Soils in Thailand. The Center for Southeast Asian Studies, Kyoto University, Kyoto (Japan)

Kawaguchi, K. and K. Kyuma 1969 b Lowland Rice Soils in Malaya. The Center for Southeast Asian Studies, Kyoto University, Kyoto (Japan)

Kawaguchi. K. and K. Kyuma 1977 Paddy Soils in Tropical Asia. The Center for Southeast Asian Studies, Kyoto University, Kyoto (Japan)

Motomura. S.. A. Seirayosakol. P. Piapongse and W. Cholitkul 1979 Field o bservations and Laboratory Analyses of Paddy Soils in Thailand (Nekken Shiryo No. 45). Tropical Agriculture Research Center, Ministry of Agriculture, Forestry and Fisheries, Japan

Takahashi, J., C. Kanareugsa. P. Sawatdee, P. Songmuang. Y. Hasathon, H. Khunathai and J. Somboondumrongkul 1979 Report on the Study of Paddy Soil Fertility of Thailand. Department of Agriculture and Cooperatives, Government of Thailand and Japan International Cooperation Agency

Wada, K., Y. Kakuto. Y. Yamada and S. Vacharotayan 1981 Clay mineralogy of paddy soils in Thailand and Malaysia. J. Fac. Agr., Kyushu Univ.. 25: 223-239 